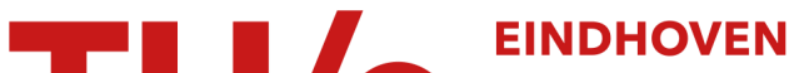 \\ UNIVERSITY OF \\ TECHNOLOGY
}

\section{An application of scenario analysis forlong-term electricity destibution network development}

\section{Citation for published version (APA):}

Du, W., Pruyt, E., Thissen, W. A. H., \& Slootweg, J. G. (2008). An application of scenario analysis forlong-term electricity destibution network development. In Proceedings 2008 first conference on Infrastructure Systems and Services: Building Networks for a Brighter Future (INFRA), Rotterdam, 10-12 Nov. 2008 (pp. 1-6) https://doi.org/10.1109/INFRA.2008.5439599

DOI:

10.1109/INFRA.2008.5439599

Document status and date:

Published: 01/01/2008

\section{Document Version:}

Publisher's PDF, also known as Version of Record (includes final page, issue and volume numbers)

\section{Please check the document version of this publication:}

- A submitted manuscript is the version of the article upon submission and before peer-review. There can be important differences between the submitted version and the official published version of record. People interested in the research are advised to contact the author for the final version of the publication, or visit the $\mathrm{DOI}$ to the publisher's website.

- The final author version and the galley proof are versions of the publication after peer review.

- The final published version features the final layout of the paper including the volume, issue and page numbers.

Link to publication

\section{General rights}

Copyright and moral rights for the publications made accessible in the public portal are retained by the authors and/or other copyright owners and it is a condition of accessing publications that users recognise and abide by the legal requirements associated with these rights.

- Users may download and print one copy of any publication from the public portal for the purpose of private study or research.

- You may not further distribute the material or use it for any profit-making activity or commercial gain

- You may freely distribute the URL identifying the publication in the public portal.

If the publication is distributed under the terms of Article $25 \mathrm{fa}$ of the Dutch Copyright Act, indicated by the "Taverne" license above, please follow below link for the End User Agreement:

www.tue.nl/taverne

Take down policy

If you believe that this document breaches copyright please contact us at:

openaccess@tue.nl

providing details and we will investigate your claim. 


\title{
An Application of Scenario Analysis for Long-term Electricity Distribution Network Development
}

\author{
W.Du, E.Pruyt, W.Thissen, J.G.Slootweg and Essent Netwerk B.V, the Netherlands
}

\begin{abstract}
This paper presents initial results of a research project entitled 'Long-term Development Strategies for Electricity Distribution Networks'. The project aims at developing and applying (new) methodologies for dealing with uncertainties in asset management, more specifically, in the development of the electricity distribution network. In this paper, a traditional methodology, i.e. scenario analysis, is applied. Scenarios are developed taking electricity distribution network operators (DNOs) as problem owner. This paper presents the scenario development processes and the resulting scenarios.
\end{abstract}

\section{INTRODUCTION}

C CENARIO development and analysis is a traditional method $\checkmark$ for long-term planning. In this paper, point scenarios are developed concerning the development of electricity distribution networks. While scenarios have been developed for energy sources and the overall electricity network [1]-[5], this paper focuses on electricity distribution networks.

The scenario analysis described in this paper is part of the research project 'Long-term Development Strategies for Electricity Distribution Networks', which is initiated and supported by Essent Netwerk B.V. ${ }^{1}$, one of the main Distribution Network Operators (DNOs) in the Netherlands. DNOs enable the distribution of electricity over distribution grids to homes and businesses [6].

The research project aims at developing and applying a whole range of existing and new methods for analyzing and dealing with uncertainties in asset management, more specifically in electricity distribution network asset management. The traditional scenario development exercise, described in this paper, will be used within this project (i) as a benchmark for comparing the application and results of innovative methods, and (ii) as plausible future states of the electricity distribution network in about 20 years, which are needed for the application of other methods.

These scenarios are developed for Essent Netwerk B.V.,in

Manuscript received at April 4, 2008. This work was supported in part by Essent, the Netherlands.

PDEng. MSc. W. Du, Policy Analysis section, Technology, Policy and Management Faculty, Delft University of Technology, the Netherlands (Tel: +31 15 2789978, Fax: + 31152784811 Email: w.du@tudelft.nl)

Dr. E. Pruyt, Policy Analysis section, Technology, Policy and Management Faculty, Delft University of Technology, the Netherlands, (Tel: +31 15 2787468, Fax: + 3115 2784811, E-mail: E.Pruyt@tudelft.nl)

Prof. W.A.H. Thissen, Policy Analysis section, Technology, Policy and Management Faculty, Delft University of Technology, the Netherlands, (Tel: $+31 \quad 15$ 2786607, Fax: + 31 15 2784811, E-mail: w.a.h.thissen@tbm.tudelft.nl)

Dr. ir. J.G. Slootweg, Essent Netwerk B.V., the Netherlands. (Tel: +31 52 3769 25, E-mail: han.slootweg@essent.nl)

${ }^{1} \mathrm{http}: / / \mathrm{www} . e s s e n t n e t w e r k . n l /$ order to assist their long-term electricity distribution network asset planning and management. However, they could also provide interesting information for other DNOs struggling with the same type of planning problems.

\section{Methodology}

The approach used in this paper is based on the scenario development steps identified by Schwartz [7], which are:

1. Identification of focal issues or decisions: to identify the focal issues or decisions of the DNOs in long-term electricity distribution network infrastructure and asset planning and development;

2. Identification of key factors in the local environment: to list the key factors influencing the success or failure of identified focal issues or decisions in the local environment;

3. Identification of driving forces: to list the driving forces that influence the identified key factors in the macro-environment;

4. Ranking by importance and uncertainty: to rank the key factors and driving forces based on (i) the degree of importance for the success of the identified focal issues or decisions; (ii) the degree of uncertainty surrounding the identified key factors and driving forces;

5. Selection of scenario logic: to determine the axes based on the ranking results along which different scenarios will be constructed;

6. Fleshing out the scenarios: to flesh out the skeletal scenarios paying attention to all the identified key factors in the developed scenarios;

7. Implications: to analyze the identified focal issues or decisions in the context of the developed scenarios;

8. Selection of leading indicators and signposts: to select leading indicators and signposts for ongoing monitoring.

\section{SCENARIO DEVELOPMENT}

In this section, scenarios are developed following the steps listed in Section II.

The information used in the paper to develop scenarios includes information provided by Essent Netwerk B.V., as well as information from other scenario studies, such as energy and network scenarios. This information is used to define key factors and driving forces (see Section C and D).

\section{A. Identification of Focal Issues or Decisions}

The focal issue or important decision that electricity 
distribution network operators (DNOs) have to make is: 'How should distribution network infrastructure and assets, including carrying sub-stations and associated operating systems, be expanded and developed taking long-term uncertainties into account?' This question could be broken down in following sub-questions:

- Should certain assets (substations and cables, etc.) be renewed or updated, and if yes, when and how?

- Should certain assets (substations and cables, etc.) be replaced by other assets with identical functionalities, and if yes, when and how?

- Should the network configurations be re-structured (re-locating substations, etc.), if yes, when and how?

- Should network infrastructure be expanded (increasing the numbers of substations, the length of cables, etc.), and if yes, when and how?

\section{B. Identification of Key Factors in the Local Environment}

Five key factors, influencing the success or failure of the decision in the local environment for DNOs, are considered: Key factor 1: Demand on the electricity distribution network

- Total electricity demand

- Total electricity demand increase and rate of increase

- Total electricity demand intensity increase and rate of increase by region

- Electricity demand curves (peak, base, daily, and seasonal loads)

Key factor 2: Electricity storage in the distribution network

- Direct electricity storage capacity

- Total electricity storage capacity

Key factor 3: Costs of distribution network components

- fixed, operational, and maintenance costs of new assets

- disposal costs of old assets

Key factor 4: Electricity price

Key factor 5: Transmission system capacity

\section{Identifying Driving Forces}

The driving forces are the influencing power behind the key factors in the social, environmental, technological, and economic macro-environment [8]. Eight potential driving forces are identified (Fig. 1 and Section F), based on the identified key factors:

Driving Force 1: Growth of renewable energy [5]

Driving Force 2: Network decentralization [3]

- Growth of scattered generation technology

- Growth of consumer self-support generation technology (smart metering and on-spot micro generation)

- Growth of scattered distribution technology

Driving Force 3: New grid technology [2]

- New transmission technology

- New distribution technology

- New storage technology

- New automated monitoring technology

Driving Force 4: Population

- Growth of the population
- Growth of the population density by region

Driving Force 5: Institutional regulations

- Authorization committees' regulations on restrained energy etc.

- Network regulators' supervisions on networking etc.

Driving Force 6: Fossil fuels demand and prices (including carbon permit, and other costs)

Driving Force 7: Security and reliability of (fuel) supply

Driving Force 8: Economic development [8]

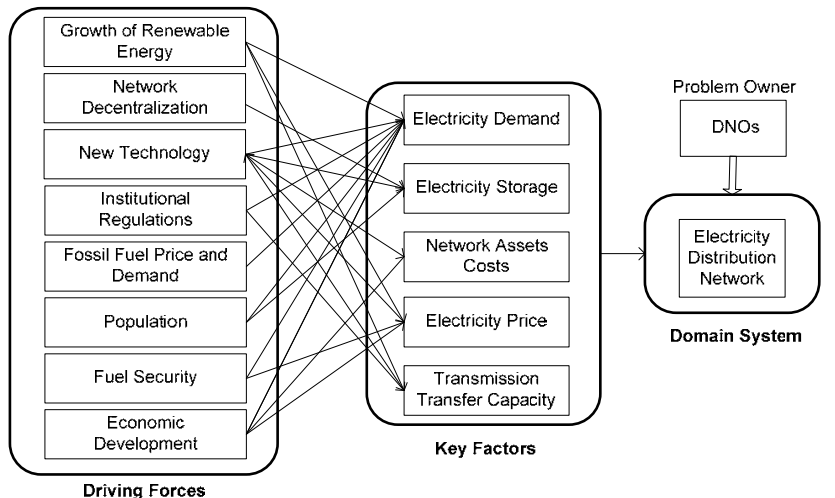

Fig.1. Potential driving forces behind identified key factors

Diving force 2, network decentralization, seems to be an important and rather uncertain driving force (see Section E). Its influence on network configurations is explored in the following paragraph.

\section{Trends in Network Decentralization}

Network decentralization could lead to various types of network re-configurations with the growth of scattered distribution, small-scale and scattered electricity generation, and growth of consumer participation. Three re-bundling network re-configurations are identified in this paper.

Type 1: Re-bundling of Scattered Generation \& Distribution:

Electricity is generated and directly supplied to the electricity distribution grid. Re-bundling electricity generation and electricity distribution may help to reduce electricity grid losses, and may also give opportunities for combinations of electricity generation technologies even by various primary sources. The re-bundling of scattered electricity generation with electricity distribution is illustrated in Fig. 2.

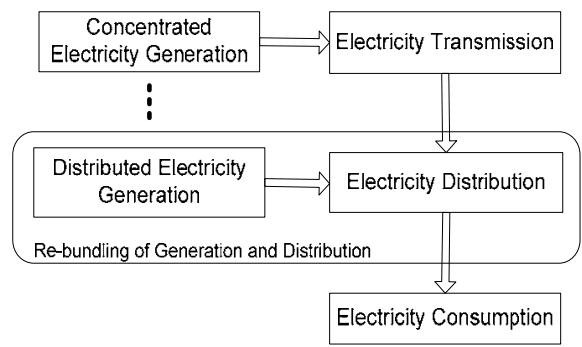

Fig. 2. Re-bundling Generation and Distribution 
Type 2: Re-bundling of Scattered Generation \& Consumption:

Scattered electricity generation can be provided to consumers directly through technologies such as solar system. This technological change may lead to demand changes in electricity distribution networks. Self-support small-scale electricity generation technologies can be applied by businesses and residents, etc. Micro CHP can be applied for decentralized electricity generation. This may help to balance the electricity voltage in the network, but may also require more automation for real-time supervision and a higher degree of compatibility between electricity systems. Also, security of supply may become a more complex issue. The re-bundling situation is illustrated in Fig. 3.

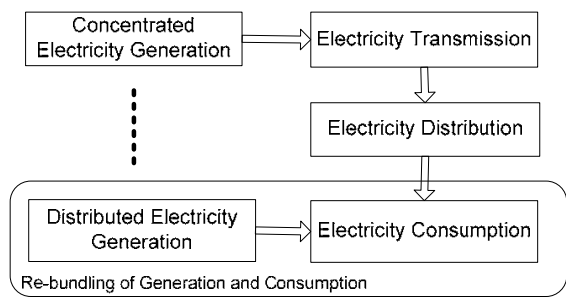

Fig. 3. Re-bundling Generation and Consumption

\section{Type 3: Re-bundling of Scattered Distribution \&} Consumption:

Small-scale electricity distribution technologies provide the possibility to re-bundle distribution and consumption. This improves the flexibilities on expanding distribution networks. The re-bundling of small, scattered distribution with consumption is illustrated in Fig. 4.

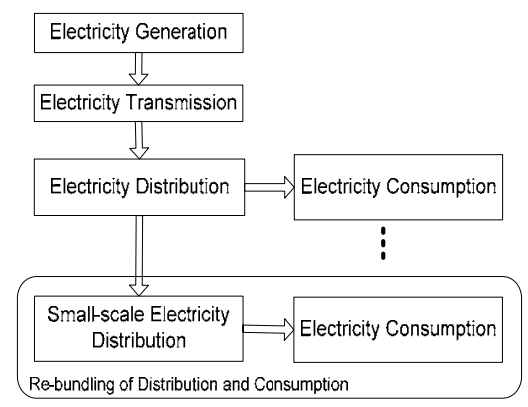

Fig. 4. Re-bundling of Distribution and Consumption

In the next section, the network decentralization ranked in the highest position, the explored three trends of network configurations are taken into account when creating scenarios (Section F).

\section{Ranking by Importance and Degree of Uncertainty}

The main factors and driving forces are ranked by the level of importance and degree of uncertainty in Table I.
TABLE I

RANKINGS BY IMPORTANCE AND UNCERTAINTY

\begin{tabular}{|c|c|c|c|}
\hline & $\begin{array}{c}\text { Level of } \\
\text { Importance }^{1}\end{array}$ & $\begin{array}{c}\text { Degree of } \\
\text { uncertainty }^{2}\end{array}$ & $\begin{array}{c}\text { Ranking } \\
\text { Place }\end{array}$ \\
\hline Electricity demand & Very important & $\begin{array}{c}\text { Highly } \\
\text { uncertain }\end{array}$ & 1 \\
\hline Electricity storage & Very important & Uncertain & 2 \\
\hline Costs of assets & Very important & $\begin{array}{c}\text { Not so } \\
\text { uncertain } \\
\end{array}$ & 3 \\
\hline Electricity price & Very important & Uncertain & 2 \\
\hline $\begin{array}{c}\text { Transmission } \\
\text { capacity }\end{array}$ & Important & $\begin{array}{c}\text { Highly } \\
\text { uncertain }\end{array}$ & 2 \\
\hline $\begin{array}{c}\text { Growth of renewable } \\
\text { energy }\end{array}$ & Very important & Uncertain & 2 \\
\hline $\begin{array}{c}\text { Network } \\
\text { decentralization } \\
\end{array}$ & Very important & $\begin{array}{c}\text { Highly } \\
\text { uncertain }\end{array}$ & 1 \\
\hline New technology & Very important & Uncertain & 2 \\
\hline Population & Very important & $\begin{array}{c}\text { Not so } \\
\text { uncertain }\end{array}$ & 3 \\
\hline $\begin{array}{c}\text { Institutional } \\
\text { Regulations } \\
\end{array}$ & Very important & $\begin{array}{c}\text { Not so } \\
\text { uncertain }\end{array}$ & 3 \\
\hline $\begin{array}{c}\text { Price and Demand of } \\
\text { fossil fuels }\end{array}$ & Important & Uncertain & 3 \\
\hline Fuel security & $\begin{array}{c}\text { Not so } \\
\text { important }\end{array}$ & $\begin{array}{c}\text { Not so } \\
\text { uncertain }\end{array}$ & 5 \\
\hline $\begin{array}{c}\text { Economic } \\
\text { Development }\end{array}$ & $\begin{array}{c}\text { Not so } \\
\text { important }\end{array}$ & Uncertain & 4 \\
\hline
\end{tabular}

Note: 1. Three levels of importance are used: very important, important, not so important; 2. Three degrees of uncertainty are used: highly uncertain, uncertain and not so uncertain.

\section{Defining ranking levels and scores}

Three levels are chosen for grading the level of importance and degree of uncertainty. The levels of importance and degrees of uncertainty cannot be defined unambiguously. The scores displayed in the table are therefore indicative, and open for discussion.

\section{Defining importance levels}

The importance levels indicate the degree to which changes in the factor or driving forces will have significant effects on future outcomes.

Defining uncertainty levels

According to [9], uncertainties can be characterized by means of three features: location, level, and nature. In Table I, only the level of the identified key factors and driving forces is identified.

The uncertainties are high and complex in the electricity network development. First, there are uncertainties originate from both technological and institutional development (see Fig.5). The uncertainties can be found in electricity generation, transmission, distribution and consumption, and also in the inter-relationships among the network components.

Also, along the electricity supply chain, not only new technologies can be invented for individual network functioning components, but the inter-relationships among the network components are also uncertain (Section 'driving forces').

At the same time, the technological changes in the network infrastructure components will lead to institutional changes among the network stakeholders in the electricity network, 
and vice versa.

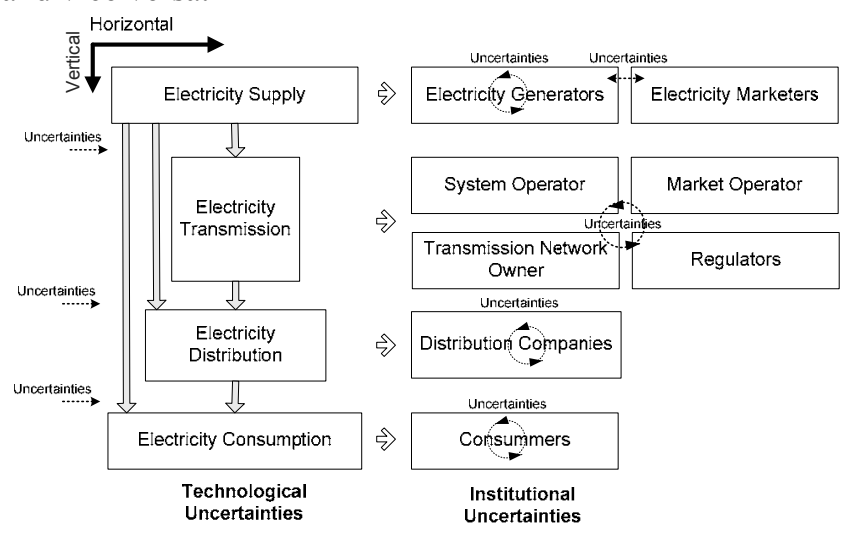

Fig. 5. Locating uncertainties in the electricity network development

As for DNOs' position in the network, they occupy a central location in the electricity supply chain which means that all the identified uncertainties in the electricity network may directly influence the distribution network development. Hence, DNOs should take all uncertainties into account in the decision-making process.

\section{E. Selecting Scenario Logics}

For practical reasons, it is advisable to limit the number of scenario drivers [7]. Two scenario logics are therefore selected here. According to Table I, demand and network decentralization are both ranked at highest. Since, network decentralization is not the driving force behind demand, they are used as the scenario logics or axes in a scenario matrix, a common used scenario approach [10] (see Fig.6).

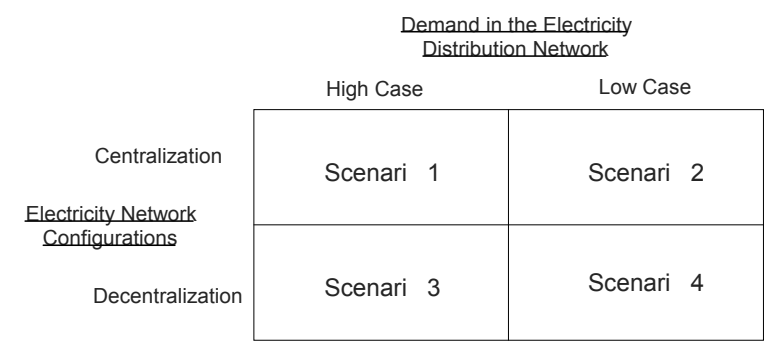

Fig. 6. Scenario Logics.

Demand: The demand should actually be explored in terms of daily, seasonal and annual, peak and base load, per region. Electricity storage might also influence these demands.

Network decentralization: Decentralized generation and distribution technology will change network configurations (see also Section 'driving forces'). Scattered self-support electricity generation and electricity storage will give consumers more opportunities to participate actively in the network, which may help to obtain clean energy policy. However, this may decrease the demand of the electricity distribution network.

More decentralized generation (micro and scattered) might not only change the technical network infrastructure, but also institutional and regulatory relationships among the network stakeholders, and even change the role of the distribution network operators in the network.

The logic pictured in Fig. 5. leads to four different scenarios:

- Scenario 1: High demand under a centralized network configuration.

- Scenario 2: Low demand under a centralized network configuration. This gives no pressure for distribution grid expansion.

- Scenario 3: High demand under decentralization, where high demand will be required in the distribution network, but decentralized generation is widely applied in the network, including small scale generation plants and self-support micro generation. The latter decreases the demand in the distribution network which is operated by DNOs.

- Scenario 4: Low demand under a decentralized network configuration, where low demand will be required in the distribution network, and decentralized generation and distribution are widely applied in the network, including small scale generation plants and self-support micro electricity generations by consumers and businesses, which may help to keep demand low.

\section{F. Fleshing Out the Scenarios}

In this section, the other identified key factors and driving forces are given some attention in each scenario to flesh out the skeletal scenarios. Since the scenarios are developed based on two axes, demand and network decentralization, so in order to flesh out the skeletal scenarios, it is helpful to first identify the relationships of these two items with other key factors and driving forces. The analysis is given by taking the high demand / network decentralization case as example.

\section{High demand}

Even though electricity demand is high, electricity prices may be low. And large transmission transfer capacities can be requested to satisfy the high demand. But higher costs will lead to higher price, which may decrease the demand. So it may be reasonable to say that replacement costs of certain network distribution assets can be not that expensive, but certainly this is not sure.

Growth of population has a positive influence on the demand, and also economic development may ask for higher demand. Fuel is one of the primary energy sources for electricity generation, therefore fuel prices have a direct influence on electricity price. But the relationship is uncertain especially for retail electricity prices [11]. The reason is complex; it may be due to for example (i) the complex mix of energy sources for electricity generation; (ii) the uncertain future percentage of renewable energy sources; (iii) fuel and electricity being alternative energy sources at final consumptions and so on.

Growth of renewable energy may lead to a higher electricity demand. However, it is not easy to assess how the 
new technology will influence the demand. For example, new electricity-based technological applications may demand more electricity; whereas, higher efficient electricity consumption technology will reduce the demand. The affect of institutional regulations on the electricity demand are also uncertain.

\section{Network decentralization}

The relationships between network decentralization and most of the key factors and driving forces are not direct and also complex, so they cannot be addressed in a linear way. But, high increase of demand intensity by regions may help to urge network decentralization. This also applies to population, which is the main driving force behind demand. And new distribution technologies especially new distribution technologies and new storage technologies will help to provide solutions for various network decentralizations. And institutional change may directly ask for network decentralization.

Based on the analysis above, it can be seen that the relationships among key factors and driving forces are complex, and it is not easy to clearly flesh out the scenarios. In the Table II, skeletal scenarios are generally fleshed out by revealing the main characteristics of corresponding key factors and driving forces in them.

TABLE II.

FLESHING OUT THE SCENARIOS

\begin{tabular}{|cl|}
\hline Scenarios & \multicolumn{1}{c|}{ Main Characteristics } \\
\hline Scenario 1: & $\begin{array}{l}\text { High electricity demand yet the network remains } \\
\text { centralized. Low electricity prices, growth of } \\
\text { renewable energy, high population, new } \\
\text { electricity-based technological applications, low } \\
\text { replacement costs of network assets }\end{array}$ \\
\hline Scenario 2: & $\begin{array}{l}\text { Low electricity demand and centralized network, } \\
\text { high electricity price }\end{array}$ \\
\hline & $\begin{array}{l}\text { Both high electricity demand and high increase of } \\
\text { electricity demand intensity by regions which } \\
\text { requires network decentralization with new } \\
\text { technology of scattered electricity generation and } \\
\text { distribution. Low electricity prices, increased } \\
\text { growth of renewable energy }\end{array}$ \\
\hline Scenario 4: & $\begin{array}{l}\text { Low electricity demand, yet certain regions may } \\
\text { have increased demand intensity which require } \\
\text { network decentralization infrastructure to satisfy } \\
\text { the needs of those regions. High electricity prices }\end{array}$ \\
\hline
\end{tabular}

\section{G. Implications}

The implications of the following four decisions under different scenario-assumptions are explored: A) Renew or update certain assets; B) Replace certain assets by new systems with identical functions; C) Re-structure the network configurations; D) Expand the network infrastructure. The implication analysis is given for the four decisions in different scenarios.

1. Decision A: It can work well in high demand scenarios, scenario 1 and 4, also can be a necessary decision for certain assets of the network even in the scenarios of low demands, depending on the aging problems.
2. Decision B: It can be another option when certain aged assets need to be renewed. And it can work well in high demand scenarios, especially will it be more cost-effective when the identical systems cost less than the original systems; however, compatibility can be a new issue if the network configuration remains the same. Also it may be a necessary decision when new network configurations are required under network decentralization, and new systems with new technology need to replace certain assets in the network.

3. Decision C: It can be a safe decision especially when high demand intensity is present in different locations. However, different network configurations are required for decentralized and centralized electricity generation.

4. Decision D: It can go well with scenarios of high demands, and also can be a necessary decision in decentralized scenarios.

Based on the analysis above, the main implications of the scenarios to the sub-decisions are summarized as Table III.

TABLE III.

IMPLICATIONS OF SCENARIOS TO DECISIONS

\begin{tabular}{|c|c|c|c|c|}
\hline & $\begin{array}{c}\text { Scenario } \\
\mathbf{1}\end{array}$ & $\begin{array}{c}\text { Scenario } \\
\mathbf{2}\end{array}$ & $\begin{array}{c}\text { Scenario } \\
\mathbf{3}\end{array}$ & $\begin{array}{c}\text { Scenario } \\
\mathbf{4}\end{array}$ \\
\hline $\begin{array}{c}\text { Decision } \\
\text { A }\end{array}$ & Fits & $\begin{array}{c}\text { Depends on } \\
\text { the demand } \\
\text { intensity by } \\
\text { region }\end{array}$ & Fits & $\begin{array}{c}\text { Depends on the } \\
\text { demand } \\
\text { intensity by } \\
\text { region }\end{array}$ \\
\hline $\begin{array}{c}\text { Decision } \\
\text { B }\end{array}$ & Fits & $\begin{array}{c}\text { Depends on } \\
\text { network } \\
\text { configuratio } \\
\text { n }\end{array}$ & Fits & $\begin{array}{c}\text { Depends on } \\
\text { network } \\
\text { configuration }\end{array}$ \\
\hline $\begin{array}{c}\text { Decision } \\
\text { C }\end{array}$ & Fits & $\begin{array}{c}\text { Depends on } \\
\text { network } \\
\text { configuratio } \\
\text { n }\end{array}$ & Fits & $\begin{array}{c}\text { Depends on } \\
\text { network } \\
\text { configuration }\end{array}$ \\
\hline $\begin{array}{c}\text { Decision } \\
\text { D }\end{array}$ & Fits & $\begin{array}{c}\text { No need } \\
\text { nits }\end{array}$ & Fits & $\begin{array}{c}\text { May fit well, } \\
\text { depending on } \\
\text { decentralized } \\
\text { architecture }\end{array}$ \\
\hline
\end{tabular}

From Table III, it can be seen that the analysis based on point scenarios can only indicate general fits or not, but is not able to give reflections on 'when and how' issues. This means that the scenario development approach maybe helpful to give the answer to DNOs in a general way on 'should do or should not do' issues, but for helping DNOs to know long-term distribution network development strategies on 'when and how' issues, other methodologies are required obviously.

\section{H. Selection of Leading Indicators and Signposts}

The leading indicators and signposts are preferable to be those that DNOs can easily and directly monitor the ongoing process for discerning scenarios. The key factor 'electricity demand' is therefore chosen. The driving force 'new technology' is also selected to be a leading signpost to monitor electricity network decentralization, especially with 
respect to new scattered electricity generation and distribution technologies and their applications.

\section{CONCLUSION}

In this paper, four scenarios are developed. One main issue and four sub-issues are identified for the electricity distribution network assets' planning and management for DNOs. One key factor and one driving force ranked highest in terms of influence on the outcomes, are selected: demand and network decentralization. The implications of alternative decisions under each of the four scenarios are explored. As one of the main driving forces, network decentralization plays an important role in scenario development for long-term electricity distribution network development. In the paper, three possible trends of long-term network re-configurations of decentralization are identified and developed in detail.

However, except for the highest ranked factor and driving force, i.e. demand and growth of decentralized generation, many other factors and driving forces rank equally high in the 2nd place, such as electricity storage, growth of renewable energy source, new technology and so on. Certainly, this is partly due to the fact that three ranking levels are chosen, but also it shows that most key factors and driving forces are all very important and uncertain, and not outstandingly distinguishable from one another.

It could also be noted that even for the main factor and driving force, another factor, i.e. electricity storage directly influences both demand and growth of decentralization. This means that these two highest ranked factor and driving force are also dependent on other factors. At the same time, active consumer participation in decentralized generation directly affect demand in the electricity distribution network as well. This indicates high uncertainties and complexities in the electricity distribution network development, and also reflects the limits of the applied point scenario analysis approach on the policy analysis of long-term electricity distribution network development.

\section{FURTHER RESEARCH}

Based on the analysis of the paper, the implications of the scenarios can only be roughly identified for 'should do or should not do' decisions. However, many factors and driving forces are inter-dependent to one another. This makes the implications on 'when and how' decisions cannot easily be identified. Thus in order to see 'when and how' policies might work in possible scenarios, further analysis approaches is needed.

Therefore, based on the information given by scenario analysis, new methodologies can be further developed or other approaches can be applied. Also new approaches can be applied to address clearly how alternative decisions will work out under different scenario-assumptions, not only 'whether or not' decisions, but also 'when and how' decisions for DNOs.
Also, in this paper, the implications of decentralization are analyzed in a consolidated way for both scattered electricity generation and scattered electricity distribution. In the further research, the implications of the decentralization of electricity generation and electricity distribution, and the identified trends of network re-configurations can be further analyzed, in order to test and know if they will have strong individual and significant influence to the long-term electricity distribution network development.

Finally, it will be worthwhile to explore the possibility of investing in flexibility options, such that adaptations to as yet uncertain future developments (such as decentralization) can be implemented more easily as the need emerges.

\section{REFERENCES}

[1] J. Watson, "UK Electricity Scenarios for 2050, Brighton: Tyndall Centre for Climate Change Research.," 2003.

[2] M. Rabinowitz, "Power Systems of the Future, IEEE Power Engineering Review," 2000.

[3] OFGEM, "LENS Project: Scenario Development Inputs, UK," 2007.

[4] I. E. G.Ault, J.McDonald, G.Burt, R.Tumilty, "Electricity Network Scenarios for 2020," 2006

[5] P. Grundy, "Shell energy scenarios to 2050," 2008.

[6] P. Williams and S. Andrews, " Embedded Generation Connection Incentives For Distribution Network Operators," Ilex Energy Consulting, UK 2002.

[7] P. Schwartz, "The Art of the Long View---Planning for the future in an uncertain world," pp. 105-117, 165-172, 241-248, 1996.

[8] J.J.Meeuwsen, "Electricity networks of the future, various roads to a sustainable energy system, Meeuwsen Power System Consultancy B.V.," 2007.

[9] W. H. Walker, P. Rotmans,J. Sluijs van der, J.P. Asselt van M.B.A. Janssen, P and Krauss, von M.P.K. , "Defining Uncertainty", Integrated Assessment," 2003.

[10] K. v. d. Heijden, "Scenarios: the art of strategic conversation; Chichester, Wiley," 2005.

[11] K. Rose, "The impact of fuel costs on electric power prices," 2007. 